\title{
Erenumab for the Prevention of Migraine, Including the Rationale, Findings and Clinical Implications of the LIBERTY Study
}

\author{
Uwe Reuter \\ Charité Universitätsmedizin Berlin, Berlin, Germany
}

DOI: https://doi.org/10.17925/ENR.2019.14.2.68

M any migraine sufferers require preventative treatment to reduce the frequency of acute attacks; however, current therapeutic options for migraine prophylaxis are associated with low efficacy and/or tolerability. Monoclonal antibodies to the calcitonin gene-related peptide (CGRP) receptor, including erenumab, fremanezumab, galcanezumab and eptinezumab, have emerged as effective treatments for migraine prevention. Fremanezumab, galcanezumab and eptinezumab target the CGRP protein, while erenumab targets the canonical receptor. A growing body of clinical data supports their efficacy and safety. While long-term data are needed, these are the first preventative drugs based on the pathophysiology of migraine, and represent a major therapeutic advance.

\section{Keywords}

Calcitonin gene-related peptide, erenumab, migraine, monoclonal antibody

Disclosure: Uwe Reuter serves as a consultant and on speaker bureaux for Amgen, Allergan, Co-Lucid, Eli Lilly, Novartis and TEVA, he is also on advisory boards for Amgen, Allergan, Eli Lilly, Novartis and TEVA. Acknowledgements: Medical writing support, including preparation of the drafts under the guidance of the author, was provided by Katrina Mountfort of Touch Medical Media.

Review Process: Double-blind peer review.

Compliance with Ethics: This article is an opinion piece and does not report on new clinical data, or any studies with human or animal subjects performed by the author.

Authorship: The named author meets the International Committee of Medical Journal Editors (ICMJE) criteria for authorship of this manuscript, takes responsibility for the integrity of the work as a whole, and has given final approval for the version to be published.

Access: This article is freely accessible at touchNEUROLOGY.com. ( ) Touch Medical Media 2020

Received: 12 September 2019

Accepted: 9 October 2019

Published Online: 16 December 2019

Citation: European Neurological Review. 2019;14(2):68-71

Corresponding Author: Uwe Reuter, Charité Universitätsmedizin Berlin,

Department of Neurology, Charitéplatz 1, 10117

Berlin, Germany. E: uwe.reuter@charite.de

Support: No funding was received for

the publication of this article.
Migraine is the most common neurological disorder and one of the most disabling health disorders worldwide, often occurring in working age, and in young adult and middle-aged women. ${ }^{1}$ It is a debilitating condition that is hard to treat, can last anywhere from 4 hours to 3 days and has a substantial negative impact on quality of life. ${ }^{2}$ Some patients treat their migraine attacks with drugs to relieve pain but, in some patients, the frequency, severity and impact on quality of life necessitates the use of preventive treatment to reduce the occurrence of acute attacks. However, in contrast to acute treatment, there are no specific treatments for migraine prophylaxis to date. A number of drugs are available, but all have been developed for other conditions, such as hypertension, depression or epilepsy. Currently available preventive therapies are associated with low adherence rates due to lack of efficacy and/or poor tolerability. ${ }^{3}$

Erenumab (Aimovigø, Novartis Pharma GmbH, Nuremberg, Germany) is a first-in-class human monoclonal antibody to the calcitonin gene-related peptide (CGRP) receptor, which is important in the pathophysiology of migraine. ${ }^{4}$ It is highly selective and has a high biological half-life, requiring monthly subcutaneous injection, and no drug titration. The clinical development of erenumab involved a number of clinical trials. A phase II study and two phase III studies showed efficacy and safety in patients with episodic migraine, ${ }^{5-7}$ and a randomised phase II trial showed efficacy and safety in patients with in chronic migraine (Table 1). ${ }^{8}$ The effective reduction of monthly headache or migraine days due to treatment could be observed very early, after less than 1 month from the first dose. The 12-week, double-blind, phase IIIb LIBERTY study aimed to answer the question of where to fit erenumab into the treatment paradigm. ' LIBERTY recruited patients who had failed 2-4 previous migraine therapies and were therefore considered difficult to treat. These represent the majority of migraine patients seen by neurologists in clinical practice, but who are often excluded from clinical studies.

A total of 246 patients were randomly assigned (1:1) to erenumab (140 mg, administered by subcutaneous injection) or placebo. At baseline, $39 \%$ of participants had previously unsuccessfully tried two preventive drugs, 93 (38\%) had tried three and 56 (23\%) had tried four. The primary endpoint was the proportion of patients achieving a reduction of at least $50 \%$ from baseline in monthly migraine days (MMDS) during weeks 9-12. At week 12, the proportion of patients achieving a reduction of at least $50 \%$ in MMDs in the erenumab group was almost three times that in the placebo group (30.3\% versus 13.7\%; odds ratio [OR] 2.7; $\mathrm{p}=0.002$ ). A larger proportion of patients in the active treatment group than in the placebo group achieved $a \geq 75 \%$ rate $(11.8 \%$ versus $4.0 \%$; OR 3.2). A $100 \%$ response rate was seen in $5.9 \%$ of the treatment group compared with none in the placebo group. The safety and tolerability of erenumab were comparable to placebo. The safety profiles of erenumab and placebo were similar. The most frequent treatment-emergent adverse event was injection-site pain, which occurred in seven (6\%) participants in both groups. ${ }^{9}$ The tolerability of erenumab is good, which is reflected by low dropout rates in all erenumab clinical trials. As a result of these findings, erenumab received approval from the European Medicines Agency (EMA) in May 2019. 
Table 1: Results of studies investigating the efficacy and safety of anti-CGRP antibodies

\begin{tabular}{|c|c|c|c|c|}
\hline & Study type & Patient population & Efficacy findings & Safety findings \\
\hline Erenumab & $\begin{array}{l}\text { Phase } \|_{1} \\
n=483^{7}\end{array}$ & $\begin{array}{l}\text { Aged } 18-60 \text { years } \\
\text { with episodic migraine } \\
\text { (4-14 MMDs) }\end{array}$ & $\begin{array}{l}\text { Mean change in MMDs at week } 12 \text { was } \\
-3.4 \text { (SE 0.4) days with erenumab } 70 \text { mg versus } \\
-2.3(0.3) \text { days with placebo (difference }-1.1 \\
\text { days [ } 95 \% \mathrm{Cl}-2.1 \text { to }-0.2], \mathrm{p}=0.021) . \text { The mean } \\
\text { reductions in MMDs with the } 7 \mathrm{mg}(-2.2 \\
\text { [SE 0.4]) and the } 21 \mathrm{mg}(-2.4 \text { [0.4]) doses were } \\
\text { not significantly different from that with placebo }\end{array}$ & $\begin{array}{l}\text { AEs in 54\% patients in placebo group, } \\
50 \% \text { patients in 7-mg group, 51\% patients } \\
\text { in the } 21-m g \text { group, and 54\% in the 70-mg } \\
\text { group. Most frequently reported AEs were } \\
\text { nasopharyngitis, fatigue, and headache. } \\
\text { Serious AEs in two patients, both unrelated } \\
\text { to treatment. 3\% had neutralising antibodies. } \\
\text { No unusual vital signs, laboratory, or } \\
\text { electrocardiogram findings }\end{array}$ \\
\hline Erenumab & $\begin{array}{l}\text { Phase } \|_{1} \\
n=667^{8}\end{array}$ & $\begin{array}{l}\text { Aged } 18-65 \text { years with } \\
\text { chronic migraine, defined } \\
\text { as } \geq 15 \text { headache days per } \\
\text { month, of which } \geq 8 \text { were } \\
\text { migraine days }\end{array}$ & $\begin{array}{l}\text { Erenumab } 70 \mathrm{mg} \text { and } 140 \mathrm{mg} \text { reduced MMDs } \\
\text { versus placebo (both doses }-6.6 \text { days versus } \\
\text { placebo }-4.2 \text { days; difference }-2.5,95 \% \mathrm{Cl}-3.5 \text { to } \\
-1.4, \mathrm{p}<0.0001 \text { ) }\end{array}$ & $\begin{array}{l}\text { AEs in 39\%, 44\% and } 47 \% \text { of placebo, 70-mg, } \\
\text { and } 140-m g \text { groups, respectively. Most } \\
\text { frequent were injection-site pain, upper } \\
\text { respiratory tract infection, and nausea. } \\
\text { Serious AEs in 2\%, 3\%, and 1\%, none led } \\
\text { to discontinuation. No clinically significant } \\
\text { abnormalities in vital signs, laboratory results, } \\
\text { or electrocardiogram findings were identified }\end{array}$ \\
\hline Erenumab & $\begin{array}{l}\text { Phase III, } \\
\text { ARISE trial, } \\
\mathrm{n}=570^{6}\end{array}$ & $\begin{array}{l}\text { Aged 18-65 years with } \\
\text { episodic migraine }\end{array}$ & $\begin{array}{l}\text { Erenumab resulted in }-2.9 \text { days change in } \\
\text { MMDs, compared with }-1.8 \text { days for placebo, } \\
\geq 50 \% \text { reduction in MMDs in } 39.7 \% \text { (erenumab) } \\
\text { and } 29.5 \% \text { (placebo) of patients (OR 1.59; } \\
95 \% \mathrm{Cl} 1.12,2.27 ; \mathrm{p}=0.010 \text { ). Migraine-specific } \\
\text { medication treatment days were reduced by } \\
-1.2 \text { (erenumab) and -0.6 (placebo) days }\end{array}$ & $\begin{array}{l}\text { Safety and adverse event profiles of } \\
\text { erenumab were similar to placebo. Most } \\
\text { frequent adverse events were upper } \\
\text { respiratory tract infection, injection-site pain, } \\
\text { and nasopharyngitis }\end{array}$ \\
\hline Erenumab & $\begin{array}{l}\text { Phase III, } \\
n=955^{5}\end{array}$ & $\begin{array}{l}\text { Aged 18-65 years with } \\
\text { episodic migraine }\end{array}$ & $\begin{array}{l}\text { Number of MMDs was reduced by } 3.2 \text { in the } \\
\text { 70-mg erenumab group and by } 3.7 \text { in the } 140 \text {-mg } \\
\text { erenumab group, compared with } 1.8 \text { days in the } \\
\text { placebo group ( } p<0.001 \text { for each dose versus } \\
\text { placebo). } \geq 50 \% \text { reduction in MMDs from baseline } \\
\text { to weeks } 13-24 \text { in } 43.3 \% \text { of patients in the } \\
70-\text { mg erenumab group and } 50.0 \% \text { of patients } \\
\text { in the } 140-m g \text { erenumab group, versus } 26.6 \% \\
\text { in the placebo group ( } p<0.001 \text { for each dose } \\
\text { versus placebo) }\end{array}$ & $\begin{array}{l}\text { Rates of adverse events were similar between } \\
\text { erenumab and placebo. Constipation and } \\
\text { muscle spasm were more frequent in the } \\
\text { 140-mg group }\end{array}$ \\
\hline Erenumab & $\begin{array}{l}\text { Phase Illb, } \\
\text { LIBERTY trial, } \\
n=246^{9}\end{array}$ & $\begin{array}{l}\text { Aged } 18-65 \text { years with } \\
\text { episodic migraine and in } \\
\text { whom previous treatment } \\
\text { with } 2-4 \text { migraine } \\
\text { preventives had been } \\
\text { unsuccessful }\end{array}$ & $\begin{array}{l}\text { At week } 12,30 \% \text { patients in the erenumab group } \\
\text { had } a \geq 50 \% \text { reduction in MMDS, compared with } \\
14 \% \text { in the placebo group (OR } 2.7 ; 95 \% \\
\mathrm{Cl} 1.4-5.2 ; \mathrm{p}=0.002 \text { ) }\end{array}$ & $\begin{array}{l}\text { Tolerability and safety profiles of erenumab } \\
\text { and placebo were similar. Most frequent TEAE } \\
\text { was injection-site pain, which occurred in } \\
\text { seven (6\%) participants in both groups }\end{array}$ \\
\hline Eptinezumab & $\begin{array}{l}\text { Phase II, } \\
n=174^{19}\end{array}$ & $\begin{array}{l}\text { Aged } 18-55 \text { years } \\
\text { with episodic migraine } \\
\text { (5-14 migraine days per } \\
\text { 28-day period) }\end{array}$ & $\begin{array}{l}\text { Mean change in migraine days between } \\
\text { baseline and weeks } 5-8 \text { was }-5.6 \text { (SD 3.0) for } \\
\text { treatment group compared with }-4.6 \text { (SD 3.6) for } \\
\text { the placebo group (difference }-1.0 ; 95 \% \mathrm{Cl}-2.0 \\
\text { to } 0.1 \text {; one-sided } p=0.0306 \text { ) }\end{array}$ & $\begin{array}{l}\text { AEs in } 57 \% \text { of treatment group and } 52 \% \\
\text { of placebo group. Most frequent AEs were } \\
\text { upper respiratory tract infection (placebo } \\
7 \% \text { patients versus treatment 9\%), urinary } \\
\text { tract infection ( } 5 \% \text { versus 1\%), fatigue (4\% } \\
\text { versus } 4 \% \text { ), back pain ( } 5 \% \text { versus } 4 \% \text { ), } \\
\text { arthralgia ( } 5 \% \text { versus 1\%), and nausea and } \\
\text { vomiting ( } 2 \% \text { versus } 4 \% \text { ). Six serious AEs } \\
\text { unrelated to study drug. No differences in } \\
\text { vital signs or laboratory safety data between } \\
\text { the two treatment groups }\end{array}$ \\
\hline Fremanezumab & $\begin{array}{l}\text { Phase III, } \\
n=1,130^{11}\end{array}$ & $\begin{array}{l}\text { Aged } 18-70 \text { years with } \\
\text { chronic migraine, defined } \\
\text { as headache of any } \\
\text { duration or severity on } \\
\geq 15 \text { days per month and } \\
\text { migraine on } \geq 8 \text { days } \\
\text { per month }\end{array}$ & $\begin{array}{l}\text { Reduction in the average number of MMDs was } \\
4.3 \pm 0.3 \text { with fremanezumab quarterly, } 4.6 \pm 0.3 \\
\text { with fremanezumab monthly, and } 2.5 \pm 0.3 \\
\text { with placebo ( } p<0.001 \text { for both comparisons } \\
\text { with placebo). } \geq 50 \% \text { reduction in MMDs in } \\
38 \% \text { of the fremanezumab-quarterly group, } \\
41 \% \text { of the fremanezumab-monthly group, } \\
\text { and } 18 \% \text { of the placebo group ( } p<0.001 \text { for } \\
\text { both comparisons with placebo) }\end{array}$ & $\begin{array}{l}\text { Abnormalities of hepatic function in five } \\
\text { patients in each fremanezumab group (1\%) } \\
\text { and three patients in the placebo group }(<1 \%)\end{array}$ \\
\hline
\end{tabular}


Table 1: Cont.

\begin{tabular}{|c|c|c|c|c|}
\hline Fremanezumab & $\begin{array}{l}\text { Phase III, } \\
\mathrm{n}=875^{13}\end{array}$ & $\begin{array}{l}\text { Aged } 18-70 \text { years } \\
\text { with episodic migraine } \\
\text { (6-14 headache days, } \\
\text { with at least } 4 \text { migraine } \\
\text { days, during } 28 \text {-day } \\
\text { pre-treatment period) }\end{array}$ & $\begin{array}{l}\text { At } 12 \text { weeks, mean migraine days per } \\
\text { month decreased from } 8.9 \text { to } 4.9 \text { days in } \\
\text { the fremanezumab monthly dosing group, } \\
\text { from } 9.2 \text { to } 5.3 \text { days in the fremanezumab } \\
\text { single-higher-dose group, and from } 9.1 \text { to } \\
6.5 \text { days in the placebo group }\end{array}$ & $\begin{array}{l}\text { Most common AEs that led to discontinuation } \\
\text { were injection-site erythema }(n=3) \text {, } \\
\text { injection-site induration }(n=2) \text {, diarrhoea }(n=2) \text {, } \\
\text { anxiety }(n=2) \text {, and depression }(n=2)\end{array}$ \\
\hline Fremanezumab & $\begin{array}{l}\text { Phase IIIb } \\
\text { FOCUS trial, } \\
n=838^{12}\end{array}$ & $\begin{array}{l}\text { Aged } 18-70 \text { years with } \\
\text { episodic or chronic } \\
\text { migraine who had } \\
\text { documented failure to } \\
2-4 \text { classes of migraine } \\
\text { preventive medications in } \\
\text { the past } 10 \text { years }\end{array}$ & $\begin{array}{l}\text { Reductions in MMDs over } 12 \text { weeks versus } \\
\text { placebo were }-0.6 \text { with quarterly fremanezumab } \\
\text { and }-4.1 \text { with monthly fremanezumab }(p<0.0001)\end{array}$ & $\begin{array}{l}\text { AEs were similar for placebo and } \\
\text { fremanezumab. Serious AEs in } 1 \% \text { of } \\
277 \text { participants on placebo, }<1 \% \text { of } \\
276 \text { with quarterly fremanezumab, and } \\
1 \% \text { of } 285 \text { with monthly fremanezumab }\end{array}$ \\
\hline Galcanezumab & $\begin{array}{l}\text { Phase III, } \\
\text { EVOLVE-1 trial, } \\
n=1,671^{14}\end{array}$ & $\begin{array}{l}\text { Aged 18-65 years with } \\
\text { episodic migraine, at } \\
\text { least a 1-year history of } \\
\text { migraine, } 4-14 \text { MMDs } \\
\text { and a mean of at least } \\
2 \text { migraine attacks per } \\
\text { month within the past } \\
3 \text { months }\end{array}$ & $\begin{array}{l}\text { Treatment with galcanezumab significantly } \\
\text { reduced MMDs (both doses } p<0.001 \text { ) by } 4.7 \text { days } \\
\text { ( } 120 \mathrm{mg} \text { ) and } 4.6 \text { days ( } 240 \mathrm{mg} \text { ) compared with } \\
\text { placebo ( } 2.8 \text { days) per } 4 \text { weeks over the entire } \\
\text { 6-month trial period }\end{array}$ & $\begin{array}{l}\text { No significant difference between treatment } \\
\text { and placebo groups, discontinuation owing to } \\
\text { AEs was }<5 \% \text { across all treatment groups }\end{array}$ \\
\hline Galcanezumab & $\begin{array}{l}\text { Phase III, } \\
\mathrm{n}=410^{15}\end{array}$ & $\begin{array}{l}\text { Aged } 18-65 \text { years with } \\
\text { episodic migraine, } \\
\text { 4-14 MMDs }\end{array}$ & $\begin{array}{l}\text { Galcanezumab } 120 \text { mg significantly reduced } \\
\text { MMDs compared with placebo ( } 99.6 \% \text { posterior } \\
\text { probability }-4.8 \text { days; } 90 \% \mathrm{BCl},-5.4 \text { to }-4.2 \text { days } \\
\text { versus } 95 \% \text { superiority threshold }-3.7 \text { days; } 90 \% \\
\mathrm{BCl},-4.1 \text { to }-3.2 \text { days) }\end{array}$ & $\begin{array}{l}\text { AEs reported by } \geq 5 \% \text { of patients in at least } \\
\text { one galcanezumab-dose group and more } \\
\text { frequently than placebo, included } \\
\text { injection-site pain, upper respiratory tract } \\
\text { infection, nasopharyngitis, dysmenorrhoea, } \\
\text { and nausea }\end{array}$ \\
\hline Galcanezumab & $\begin{array}{l}\text { Phase III, } \\
\text { EVOLVE-2 trial, } \\
n=915^{16}\end{array}$ & $\begin{array}{l}\text { Aged } 18-65 \text { years with } \\
\text { episodic migraine }\end{array}$ & $\begin{array}{l}\text { MMDs were reduced by } 4.3 \text { and } 4.2 \text { days by } \\
\text { galcanezumab } 120 \text { and } 240 \text { mg, respectively, and } \\
2.3 \text { days by placebo }\end{array}$ & $\begin{array}{l}\text { Both galcanezumab doses had significantly } \\
\text { more injection-site reactions and } \\
\text { injection-site pruritus, and the } 240 \text {-mg group } \\
\text { had significantly more injection-site erythema } \\
\text { versus placebo }\end{array}$ \\
\hline Galcanezumab & $\begin{array}{l}\text { Phase III, } \\
\text { REGAIN trial, } \\
n=1,113^{17}\end{array}$ & $\begin{array}{l}\text { Aged } 18-65 \text { years with } \\
\text { episodic migraine }\end{array}$ & $\begin{array}{l}\text { Both galcanezumab dose groups significantly } \\
\text { reduced MMDs compared with placebo (placebo } \\
-2.7 \text {, galcanezumab } 120 \mathrm{mg}-4.8 \text {, galcanezumab } \\
240 \mathrm{mg}-4.6 ; \text { p }<0.001 \text { for each dose compared } \\
\text { with placebo) }\end{array}$ & $\begin{array}{l}\text { No clinically meaningful differences between } \\
\text { galcanezumab doses and placebo except for } \\
\text { a higher incidence of treatment-emergent } \\
\text { injection-site reaction ( } p<0.01) \text {, } \\
\text { injection-site erythema }(p<0.001) \text {, } \\
\text { injection-site pruritus }(p<0.01) \text {, and sinusitis } \\
(p<0.05) \text { in the galcanezumab } 240 \text {-mg group } \\
\text { relative to placebo }\end{array}$ \\
\hline
\end{tabular}

$A E S=$ adverse events; $B C l=$ Bayesian credible intervals; $C G R P=$ calcitonin gene-related peptide; $\mathrm{Cl}=$ confidence interval; $M M D S=$ monthly migraine days; $O R=$ odds ratio; $S D=$ standard deviation; $S E=$ standard error; TEAE = treatment-emergent adverse event.

The implications of these findings are important for clinical practice as, for the first time, clinicians and patients have the option of a drug based on the pathophysiology of migraine. Erenumab shows a low risk for drug-drug interactions and hepatotoxicity since it is metabolised by degradation into peptides and single amino acids, ${ }^{10}$ an important consideration for patients using multiple medications.

Since the approval of erenumab, two other anti-CGRP monoclonal antibodies, fremanezumab (Ajovy ${ }^{\circledast}$, Teva, Petah Tikva, Israel) $)^{11-13}$ and galcanezumab (Emgality ${ }^{\mathrm{TM}}$, Eli Lilly, Indianapolis, IN, USA), ${ }^{14-18}$ have received European Medicines Agency approval for migraine prevention, with a fourth agent, eptinezumab, in clinical development (Table 1).19 The most important difference between the drugs is that fremanezumab, galcanezumab and eptinezumab target the CGRP protein, while erenumab targets the canonical receptor. The implications of this difference in terms efficacy and safety are not yet known. Importantly, to date, the LIBERTY, FOCUS (fremanezumab) ${ }^{12}$ and recent CONQUER (galcanezumab) trials ${ }^{16}$ have included patients treated unsuccessfully with between two and four preventive treatments (Table 1). The efficacy of eptinezumab remains untested for patients with severe, treatment-resistant migraine.

There are potential limitations to the use of anti-CGRP antibodies. The duration of trials, to date, is not sufficient to determine the long-term effects of continuingly blocking CGRP or its receptor. CGRP is an ubiquitous peptide that is not only involved in migraine, but also in several other physiological processes. ${ }^{20}$ Since this is a new drug class, continued monitoring of efficacy and safety, including production of toxic metabolites, and the production neutralizing antibodies, is important. ${ }^{21}$ In the cardiovascular system, CGRP is present in nerve fibres that innervate blood vessels and the heart and are involved in the regulation of blood pressure. ${ }^{22,23}$ Patients with cardiovascular and cerebrovascular disease were, therefore, excluded from clinical trials. Although no increased incidence of cardiovascular events was reported in the clinical 
trial, further studies should examine the cardiovascular effects of the long-term, continuous blockade of the CGRP pathway.

One potential barrier to the widespread use of these agents is cost; the price of the drugs has to be taken into consideration when deciding whether to use CGRP antibodies as a prophylactic treatment and which patient groups to treat. The Institute for Clinical and Economic Review concluded that CGRP inhibitors are cost-effective in the long-term but could potentially have a significant impact on short-term health budgets. ${ }^{24}$ The LIBERTY study has identified an important subgroup of migraine sufferers who will derive benefit from treatment, increasing its cost-effectiveness.

In summary, on the basis of current evidence, anti-CGRP antibodies have the potential to improve the lives of millions of people suffering from frequent migraines. Erenumab appears to be a particularly attractive option for patients with difficult-to-treat migraine who have high unmet needs and few treatment options. $\mathrm{c}$
1. GBD 2016 Headache Collaborators. Global, regional, and national burden of migraine and tension-type headache, 1990-2016: a systematic analysis for the global burden of 1990-2016: a systematic analysis for the global burden

2. Lipton RB, Hamelsky SW, Kolodner KB, et al. Migraine, quality of life, and depression: a population-based case-control study. Neurology. 2000;55:629-35

3. Hepp Z, Dodick DW, Varon SF, et al. Persistence and switching patterns of oral migraine prophylactic medications among patients with chronic migraine: a retrospective claims analysis. Cephalalgia. 2017;37:470-85.

4. Goadsby PJ, Holland PR, Martins-Oliveira M, et al. Pathophysiology of migraine: a disorder of sensory processing. Physiol Rev. 2017;97:553-622.

5. Goadsby PJ, Reuter U, Hallstrom Y, et al. A controlled trial of erenumab for episodic migraine $N$ Eng/ 」 Med. 2017:377:2123-32

6 . Dodick DW Ashina M Brandes Ut, et al ARISE. A phase Dedick DW, Ashina Cephalalgia. 2018:38:1026-37.

7. Sun H, Dodick DW, Silberstein S, et al. Safety and efficacy of AMG 334 for prevention of episodic migraine: a randomised double-blind, placebo-controlled, phase 2 trial. Lancet Neuro 2016;15:382-90

8. Tepper S, Ashina M, Reuter U, et al. Safety and efficacy of erenumab for preventive treatment of chronic migraine: randomised, double-blind, placebo-controlled phase 2 trial. Lancet Neurol. 2017;16:425-34.

9. Reuter U, Goadsby PJ, Lanteri-Minet M, et al. Efficacy and tolerability of erenumab in patients with episodic migrain in whom two-to-four previous preventive treatments were unsuccessful: a randomised, double-blind, placebo-controlled, phase 3b study. Lancet. 2018;392:2280-7.

10. Zho $\mathrm{H}$ Mascelli MA Mechanisms of monoclonal antibody-drug interactions. Annu Rev Pharmacol Toxicol. 2011;51:359-72.

11. Silberstein SD, Dodick DW, Bigal ME, et al. Fremanezumab for the preventive treatment of chronic migraine. N Eng/ J Med 2017;377:2113-22.

12. Ferrari MD, Diener $H C$, Ning $X$, et al. Fremanezumab versus placebo for migraine prevention in patients with documented failure to up to four migraine preventive medication classes (FOCUS): a randomised, double-blind, placebo-controlled, phase 3b trial. Lancet. 2019;394:1030-40.

13. Dodick DW, Silberstein SD, Bigal ME, et al. Effect of fremanezumab compared with placebo for prevention of episodic migraine: a randomized clinical trial. JAMA 2018;319:1999-2008.

14. Stauffer VL, Dodick DW, Zhang $Q$, et al. Evaluation of galcanezumab for the prevention of episodic migraine: the EVOLVE-1 randomized clinical trial. JAMA Neurol. 2018;75:1080-8.

15. Skljarevski V, Oakes TM, Zhang Q, et al. Effect of different doses of galcanezumab vs placebo for episodic migraine prevention a randomized clinical trial. JAMA Neurol. 2018;75:187-93

16. Skljarevski V, Matharu M, Millen BA, et al. Efficacy and safety of galcanezumab for the prevention of episodic migraine: results of the EVOLVE-2 phase 3 randomized controlled clinical trial. Cephalalgia. 2018;38:1442-54.

17. Detke HC, Goadsby PJ, Wang S, et al. Galcanezumab in chronic migraine: the randomized, double-blind, placebo-controlled REGAIN study. Neurology. 2018;91:e2211-21.

18. Eli Lilly and Company. Lilly Announces Positive Results for Emgality (galcanezumab-gnlm) from the CONQUER Study in Patients who Failed Previous Migraine Preventive Treatments [press release]. Available at: www.prnewswire.com/ news-releases/illy-announces-positive-results-for-emgalitygalcanezumab-gnlm-from-the-conquer-study-in-patients-whofailed-previous-migraine-preventive-treatments-300895947. html (accessed 16 October 2019)

19. Dodick DW, Goadsby PJ, Silberstein SD, et al. Safety and efficacy of ALD403, an antibody to calcitonin gene-related peptide, for the prevention of frequent episodic migraine: a randomised double-blind, placebo-controlled, exploratory phase 2 trial. Lancet Neurol. 2014;13:1100-7.

20. Raffaelli B, Reuter U. The biology of monoclonal antibodies: focus on calcitonin gene-related peptide for prophylactic migraine therapy. Neurotherapeutics. 2018;15:324-35

21. Russell FA, King R, Smillie SJ, et al. Calcitonin gene-related peptide: physiology and pathophysiology. Physiol Rev. 2014;94:1099-142

22. Taylor FR. CGRP, amylin, immunology, and headache medicine. Headache. 2019;59:131-50

23. Kee Z, Kodji X, Brain SD. The role of calcitonin gene related peptide (CGRP) in neurogenic vasodilation and its cardioprotective effects. Front Physiol. 2018;9:1249.

24. Institute for Clinical and Economic Review (ICER). Migraine: evidence report. Available at: https://icer-review.org/materia/ cgrp-evidence-report/ (accessed 2 May 2019). 